\title{
Nota da Presidência
}

Tenho especial satisfação em escrever estas breves linhas nesta nota de edição da Paraná Eleitoral - Revista Brasileira de Direito Eleitoral e Ciência Política, v. 4. n. 2. Orgulha-me fazê-lo porque tive o privilégio, ainda na qualidade de servidor desta Casa, de acompanhar o desenvolvimento deste periódico desde a década de 1980.

Participei da elaboração da revista de número 1 e recordo-me que, na época, a sua confecção era artesanal, datilografada pelos servidores e, posteriormente, reproduzida em mimeógrafos.

Recordo-me também que, na produção da revista de número 1, participaram comigo da sua elaboração as servidoras Maria Luíza Bernstorff Gualberto e Mariana Pilastre de Goes, minha mulher.

Oportuno registrar que a Revista Paraná Eleitoral foi criada em 1955, teve paralisada sua edição durante o Regime de Exceção, sendo retomada somente após a reabertura política.

Já na primeira edição dessa nova etapa, contou-se com a participação de um juiz-membro da Corte, doutor Egas Dirceu Moniz de Aragão, um dos maiores processualistas brasileiros que explorou o tema "Sistema de Preclusões e o Procedimento Eleitoral".

Naquela época, o direito eleitoral era incipiente, sendo esparsa a produção de artigos técnicos sobre o tema. O texto do eminente professor Moniz de Aragão, marco do reinício das atividades da revista, certamente, foi um prenúncio do que vinha pela frente.

De fato, a partir do ano 2000, a revista passou a dispor do maior acervo de direito eleitoral do país, onde perfilaram grandes eleitoralistas, seguindo até o número 74 , sendo possível a consulta de todos os exemplares no endereço eletrônico http://www.tre-pr.jus.br/institucional/revista-parana-eleitoral/acervos-1/parana-eleitoral-acervo.

Agora, transformada em revista acadêmica, constitui-se num espaço único e diferente, unindo o direito eleitoral e a ciência política, disciplinas afins que se mesclam a investigar e lançar luzes no estudo do conhecimento e do fenômeno jurídico e político eleitoral.

Congratulo toda a equipe de editores, colaboradores e autores, cônscio do trabalho árduo que é a confecção de um periódico e do prazer e satisfação em vê-lo publicado. 